\title{
Lumbar Ligamentum Flavum Cyst: Case Report
}

\begin{abstract}
Ligamentum flavum cyst, a cystic lesion adjacent to the lumbar spine, is a rare cause of neurological symptoms and signs. It is usually seen in older ages. It is more common in the lower lumbar region than in the cervical region. Here, we aimed to discuss ligamentum flavum cysts in two cases.

In a 54-year-old male, a lumbar magnetic resonance imaging showed a ligamentum flavum cyst located at the right posterolateral of the spinal canal at the L3-L4 level, and spinal canal stenosis at this level. After the surgical removal of the cyst, the patient's symptoms entirely resolved. A 43-yearold female patient had a ligamentum flavum cyst on the left posterolateral of the spinal at L4-L5 level with thecal sac compression. Conservative treatment was planned, and the symptoms regressed during follow-up.
\end{abstract} \\ Keywords: Ligamentum flavum cyst, radiculopathy, lumbar \\ vertebra, magnetic resonance imaging
}

Lomber Düzeyde Ligamentum Flavum Kisti: Olgu Sunumu

(D) Veysel Kaplanoğlu1, (D) Hatice Kaplanoğlu², (D) Özlem Güngör1, (D) Cansu Öztürk¹, (D) Selma Uysal Ramadan1

1 University of Health Sciences, Ankara Keçiören Training and Research Hospital, Clinic of Radiology, Ankara, Turkey

2University of Health Sciences, Dıșkapı Yıldırım Beyazıt Training and Research Hospital, Clinic of Radiology, Ankara, Turkey

\section{öZ}

Lomber vertebra komşuluğunda kistik bir lezyon olan ligamentum flavum kistleri nörolojik semptom ve bulguların nadir bir nedenidir. Genellikle ileri yașlarda görülür. Alt lomber bölgede, servikal bölgeye göre daha sıktır. Burada iki olgu dahilinde ligamentum flavum kistlerini tartışmak amaçlanmıștır.

Elli dört yaşında erkek olguda, lomber magnetik rezonans görüntülemede, L3-L4 seviyesinde spinal kanal sağ posterolateralinde yerleșen bir ligamentum flavum kisti ve buna bağıı bu seviyede spinal kanalda daralma görüntülendi. Kist cerrahi yöntemle çıkartıldıktan sonra olgunun yakınmaları tamamen düzeldi. Kırk üç yaşında kadın olguda, L4-L5 düzeyinde sol posterolateralde tekal saka indentasyon gösteren, ligamentum flavum kisti saptandı. Hastaya konservatif tedavi planlandı ve takipte semptomların gerilediği görüldü.

Anahtar Kelimeler: Ligamentum flavum kisti, radikülopati, lomber vertebra, manyetik rezonans görüntüleme

\section{Introduction}

The term ligamentum flavum cyst is defined as a cystic formation arising from ligamentum flavum that is not lined with synovial epithelium (1). Ligamentum flavum cyst is a rare cause of spinal cord and nerve compression (2). It was first defined by Moiel et al. (3) in 1967. It occurs most frequently in the lower lumbar region (4). It may cause neurological complaints due to spinal canal stenosis or lumbar root compression (5). These cysts accompany degenerative changes in the spine. It can be distinguished from synovial and other degenerative spinal cysts based on localization and histopathological features (6). We aimed to present two cases of ligamentum flavum cysts that we diagnosed based on original magnetic resonance imaging (MRI) findings and confirmed one histopathologically.

\section{Case Reports}

\section{Case 1}

A lumbar MRI was requested for a 54-year-old male patient with low back pain, slow-developing gait disturbance, hip, and right leg pain. Neurological examination revealed normal motor functions, but sensory impairment in the right $L 4$ dermatome. The patient's medical history included hypertension and diabetes. No pathology was observed in laboratory tests. Degenerative changes were observed on the direct X-ray of the lumbosacral vertebra. Multilevel facet arthropathy, more prominent in L3-L4, was observed in lumbar MRI. A $17 \times 5.5 \mathrm{~mm}$ ligamentum flavum cyst, which was hypointense on T1-weighted images (T1WI) and hyperintense on T2-WI, was found at L3-L4 level. The cyst caused right lateral recess stenosis by compressing thecal sac and spinal 
cord from the right lateral side, and it was not related to the facet joint (Figure 1 a,b). At this level, significant stenosis was observed in the spinal canal due to cyst and ligamentum flavum hypertrophy. Since the patient refused, electromyography (EMG) was not performed. The cyst was surgically resected with hypertrophic ligamentum flavum, and partial L3-L4 hemilaminectomy was performed. Histopathological examination revealed myxoid and pseudocystic degeneration of the ligamentum flavum without synovial epithelium. In the postoperative period, the patient's symptoms improved, and he recovered without any problem. Informed consent was obtained.

\section{Case 2}

A 43-year-old female patient presented with chronic low back pain and progressive neurogenic claudication symptoms over a 6-month period. There were no features in her medical and family history. There was no motor or sensory disorder in her neurological examination. Deep tendon reflexes were normal. Laboratory tests were normal. MRI revealed a 11x8.5 mm ligamentum flavum cyst, which was hypointense on T1WI and hyperintense on T2WI, at L4-L5 level on the left with thecal sac indentation (Figure $2 \mathrm{a}, \mathrm{b}$ ). Diffuse bulging of the disc and facet joint degeneration were detected at this level. EMG was not performed. Conservative treatment was planned because the patient did not accept the surgery, and the symptoms regressed during the follow-up. Informed consent was obtained.

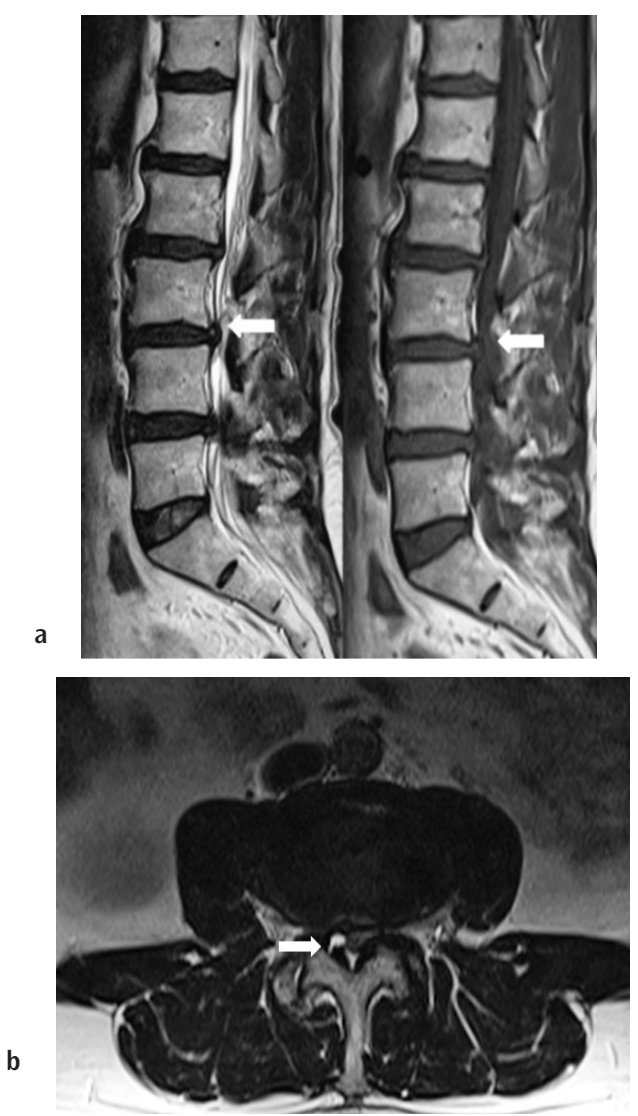

Figure 1. a) Sagittal T1-weighted imaging (T1WI) and T2-WI); b) axial magnetic resonance imaging showing cystic lesion (arrows) in the thickened ligamentum flavum at the L3-L4 intervertebral level, which is hypointense on T1WI and hyperintense on T2W images

\section{Discussion}

The term ligamentum flavum cyst is defined as a cystic formation originating from ligamentum flavum that is not lined with synovial epithelium (1). Ligamentum flavum cyst is a juxtafacet cyst, and it is thought that continuous stress caused by small recurrent trauma may cause cyst development (7).

While these cysts are frequently seen in lumbar vertebrae, they are also rarely found in cervical vertebrae (8). The most commonly reported level is L4-L5, the most mobile part of the vertebra, followed by L5S1 and L3-L4 levels (4). Osteoarthritis, spondylosis, spondylolisthesis, and degenerative disc disease are common with vertebra cysts (9). Most ligamentum flavum cysts develop posterolaterally near the facet joint in the spinal canal (10). Most symptomatic cysts usually present with radiculopathy. The history and physical examination findings of these patients may resemble symptoms related to sciatica and disc herniation (11). Typically, cysts can cause radicular pain (97\%), sensory (55\%) or motor (39\%) deficit, Lasèque sign (33\%), abnormal reflexes (18\%), and rarely present as cauda equina syndrome (1).

Ligamentum flavum cysts can be easily identified by MRI. The cysts are characteristically hypointense on T1WI and hyperintense on T2WI. The presence of blood, gas, air, or proteinaceous content may change the signal intensity (4). Conservative treatment has proved to be
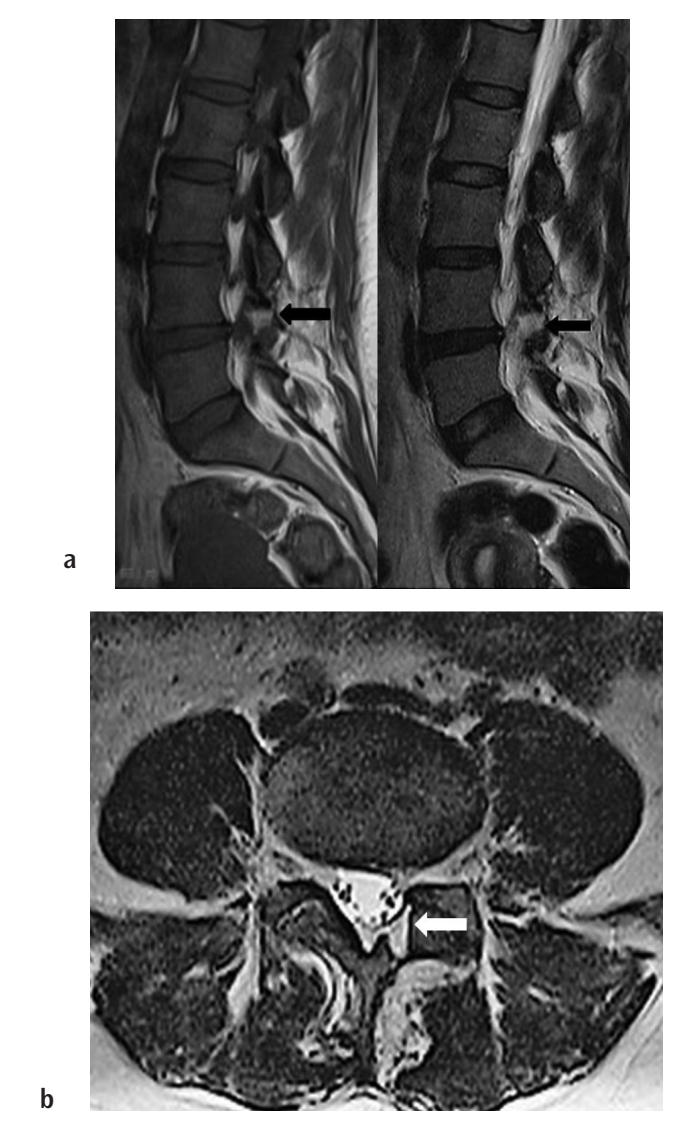

Figure 2. a) Sagittal T1-weighted imaging (T1WI) and T2-WI); b) Axial T2WI showing hyperintense cystic lesion (arrows) in the ligamentum flavum on the left at the L4-L5 intervertebral level 
unsuccessful and has transient and unreliable short-term outcomes. Surgical treatment is the gold standard in patients with severe pain and neurological deficit (12). Surgical decompression with complete excision of the ligamentum flavum cyst is the most successful treatment strategy and has excellent results (12). Instrumentation is performed only if facetectomy is performed or other pathologies are present (8).

Although the ligamentum flavum cyst is a rare cause of spinal compression and radiculopathy, it should be considered in the differential diagnosis of cystic lesions of the lumbar spinal canal. Preoperative diagnosis is not easy due to its rare and nonspecific clinical and radiological findings. MRI is the best imaging method to help us with this.

Informed Consent: Informed consent was obtained.

Peer-review: Externally peer-reviewed.

Author Contributions: Surgical and Medical Practices - V.K.; Concept V.K., H.K., Ö.G.; Design - H.K., S.U.R.; Data Collection and/or Processing - V.K., C.Ö.; Analysis and/ or Interpretation - Ö.G., S.U.R; Literature Search - H.K., C.Ö.; Writing Manuscript - H.K.

Conflict of Interest: No conflict of interest was declared by the authors.

Financial Disclosure: The authors declared that this study received no financial support.

\section{References}

1. Shah K, Segui D, Gonzalez-Arias S. Midline ligamentum flavum cyst of lumbar spine. World Neurosurg 2018; 110: 284-87.
2. Savitz MH, Sachdev VP. Cyst of the ligamentum flavum: Report of six cases. Neurosurgery 1992; 30: 461-2.

3. Moiel RH, Ehni G, Anderson MS. Nodule of the ligamentum flavum as a cause of nerve root compression. Case report. J Neurosurg 1967; 27: 456-8.

4. Seo DH, Park HR, Oh JS, Doh JW. Ligamentum flavum cyst of lumbar spine: A case report and literature review. Korean J Spine 2014; 11: 18-21.

5. Gazzeri R, Galarza M, Gorgoglione L, Bisceglia M, D’Angelo V. Cervical cyst of the ligamentum flavum and C7-T1 subluxation: case report. Eur Spine J 2005; 14: 807-9.

6. Muzii VF, Tanganelli P, Signori G, Zalaffi A. Ganglion cyst of the ligamentum flavum: a rare cause of cervical spinal cord compression. Journal of Neurology, Neurosurgery and Psychiatry 2010; 81: 940-1.

7. Chan L, Lui C, Cheng M, Lin J. Ganglion cyst in the ligamentum flavum of the cervicothoracic junction. J Formos Med Assoc 1996; 95: 490-2.

8. Brotis AG, Kapsalaki EZ, Papadopoulos EK, Fountas KN: A cervical ligamentum flavum cyst in an 82-year-old woman presenting with spinal cord compression: A case report and review of the literature. J Med Case Rep 2012; 6: 92.

9. Benzel EC: Lumbar juxtafacet cysts: simply an extension of the lumbar degenerative process. World Neurosurg 2005; 77: 65-6.

10. Hatem O, Bedou G, Négre C, Bertrand JL, Camo J: Intraspinal cervical degenerative cyst. Report of three cases. J Neurosurg 2001; 95: 139-42.

11. Desai AA, Trivedi A, Chandraker BL, Kadam R. Report of a rare case: ligamentum flavum cyst. MGM J Med Scu 2015; 2: 208-12.

12. Kim J, Choi JG, Son BC. Bilateral ganglion cysts of the ligamentum flavum in the cervical spine causing a progressive cervical radiculomyelopathy and literature review. Case Rep Neurol Med 2017; 2017: 3953641. 